\title{
Strategi Pengembangan IPS Melalui Konsep Waktu, Perubahan Dan Kebudayaan sebagai Transmisi Kewarganegaraan Dalam Pembelajaran
}

\author{
A. Gafar Hidayat ${ }^{1, *}$ Tati Haryati $^{1)}$, Ratnah ${ }^{1)}$ \\ ${ }^{1)}$ STKIP Taman Siswa Bima \\ *gafarhidayat@gmail.com
}

Artikel Info

Tanggal Publikasi

2020-12-20

Kata Kunci

Strategi

Pengembangan IPS

Waktu

Perubahan

Kebudayaan

\section{Abstrak}

Pembelajaran IPS merupakan hasil fusi secara terpadu, sebagai hasil seleksi dan penyederhanaan dari berbagai ilmu-ilmu sosial untuk kepentingan tujuan pembelajaran, serta disesuaikan dengan tingkatan pendidikan. Oleh karena itu IPS merupakan program pembelajaran yang dijadikan sebagai instrumen pewarisan budaya bangsa melalui transmisi kewarganegaraan. Tujuan penulisan ini yaitu untuk memahami strategi mengembangkan IPS melalui konsep waktu, perubahan dan kebudayaan. Metode penulisan ini menggunakan studi literatur atau telaah pustaka, dan dideskripsikan secara kualitatif. Adapun hasil dari penulisan ini yaitu strategi pengembangan IPS melaui konsep waktu, perubahan, dan kebudayaan dalam pembelajaran ilmu sosial erat kaitannya dengan ilmu sejarah yang meliputi masa lalu, masa sekarang dan yang akan datang, begitu juga dalam pembelajaran ilmu sosial lainnya, yang diintegrasikan secara terpadu dalam pembelajaran IPS, agar pemahaman siswa bersifat holistik. Perubahan merupakan gejala yang umum terjadi pada masyarakat manusia. Dalam konteks kehidupan manusia sebagai makhluk sosial dikenal dua macam perubahan yaitu perubahan sosial (social change) dan perubahan kebudayaan (cultural change). Sedangkan kebudayaan adalah hasil dari daya dari budi yang berupa cipta, rasa, dan karsa, manusia sebagai nilai yang dijunjung tinggi dan membentuk aturan yang disepakati besara untuk kepentingan bersama anggota kelompok masyarakat. Dengan kata lain, hasil dari ketiga unsur akal atau budi (cipta, rasa, dan karsa) itulah yang disebut dengan kebudayaan.

\section{PENDAHULUAN}

Dewasa ini perkembangan ilmu sosial diberbagai cabang dan disiplin ilmu berkembang dengan begitu pesat, seiring dengan komleksnya perkembangan kehidupan manusia, yang terintegrasi dalam kajian dan pembelajaran Ilmu Pengetahuan Sosial (IPS) yang. Pembelajaran IPS merupakan hasil fusi secara terpadu, baik secara seleksi maupun penyederhanaan ilmu-ilmu sosial untuk kepentingan tujuan pembelajaran yang disesuaikan dengan tingkatan pendidikan.

Segala aspek yang berkaitan dengan kelangsungan kehidupan manusia tidak terlepas dari, kajian ilmu sosial, dan dan menjadi perhatian penuh bertumpu pada aktifitas yang buat olehh manusia, tentu dalam hal ini tidak terlepas dari konsep waktu, perubahan dan kebudayaan sebagai hasil cipta manusia, baik sebagai mahluk individu, maupun kelompok. Waktu merupakan salah satu konsep dasar sejarah dan ilmu-ilmu sosial lainnya, selain ruang dan kegiatan manusia, perubahan dan kesinambungan ini merupakan unsur penting dari sejarah yaitu masa lalu. Sejarah dan ilmu sosil merupakan proses perjalanan waktu yang sangat luas dan panjang. Sejarawan Ingin membuat waktu yang terus-menerus bergerak menjadi tanpa berhenti itu dapat dipahami dengan membagi-baginya dalam unit-unit waktu. Suatu momentum yang dapat memberikan petunjuk adanya karakteristlk dari suatu kurun waktu yang satu berbeda dari kurun waktu lainnya. Inilah yang dinamakan periodisasi/pembabakan waktu. Jadi sejarah adalah suatu peristiwa dalam suatu rentang waktu yang langsung terus-menerus yang melibatkan perubahan dalam kehidupan manusia. Periodisasi/pembabakan waktu adalait salah satu produk 
penulisan sejarah dalam rangka memahami rangkaian peristiwa tersebut yang didasarkan pada momentum perubahan sebagai tanda pemisahan waktu.

Oleh karena itu pembahasan yang berhubungan dengan waktu, perubahan dan kebudayaan harus bersifat integratif dan tidak bisa dipisahkan satu dengan yang lain. hal ini menjadi pusat perhatian penulis untuk mengkaji sejauh mana, hubungan antara tiga konsep tersebut untuk, menjeskan beberapa fenomena dan rentetan peristiwa yang bersifat kausalitas dalam kajian ilmu sosial, atau ilmu pengetahuan sosial.

\section{METODE PENULISAN}

Penulisan ini menggunakan teknik studi pustaka atau telaah literatur dari berbagai sumber teori maupun buku dan jurnal. Disajikan secara deskritif kualitatif.

\section{HASIL DAN PEMBAHASAN}

\section{Konsep Waktu dalam Ilmu Sosial}

Waktu (dimensi temporal memiliki dua makna, yaitu makna konotatif dan makna denotatif. Makna waktu secara denotatif adalah suatu kesatuan: detik, menit, jam, hari, minggu, bulan, tahun, abad, dan seterusnya. Sedangkan makna waktu secara konotatif adalah waktu sebagai suatu konsep. Ruang (dimensi spasial) merupakan tempat terjadinya berbagai peristiwa, baik peristiwa alam maupun peristiwa sosial dan peristiwa sejarah dalam proses perjalanan waktu. Manusia (dimensi manusia) adalah pelaku dalam peristiwa sosial dan peristiwa sejarah. Dengan demikian, ketiga konsep tersebut tidak dapat dipisahkan dalam suatu peristiwa dan perubahannya.

Suatu peristiwa dipengaruhi oleh kekuatan di luar manusia yaitu berupa kekuatan fi sik-material (dimensi alam). Kekuatan-kekuatan tersebut merupakan suatu potensi bagi terjadinya suatu peristiwa. Kemungkinan terjadinya peristiwa-peristiwa tersebut dapat tercermin dalam suatu peristiwa yang membawa perubahan terhadap manusia dalam dimensi ruang dan waktu secara fungsional dan terhubung. Proses terjadinya suatu peristiwa dan perubahannya berlangsung.

Dalam batas ruang dan waktu. Dengan batas ruang, diadakan pengkajian tentang peristiwa dan perkembangannya. Namun, dengan berkembangnya IPTEK dalam bidang komunikasi, maka batas ruang menjadi tidak berarti karena suatu peristiwa akan dengan mudah menyebar ke ruang yang lebih luas seolah-olah ruang tempat terjadinya peristiwa tersebut bergerak.

Kata sejarah berasal dari bahas Arab "Syajara" artinya pohon yang memiliki cabang, dahan, daun dan ranting. Begitu pula dengan pertumbuhan manusia.Disamping sejarah dikenal juga kata silsilah.Sejarah adalah semua pertistiwa masa lampau (sejarah sebagai kenyataan). Sejarah dapat membantu para siswa memahami perilaku manusia pada masa yang lampau, masa sekarang dan masa yang akan datang. (tujuan-tujuan baru pendidikan sejarah)

Tugas pokok ilmu sejarah berkaitan dengan waktu adalah ilmu sejarah bertugas membuka ke masa lampau/waktu yang lalu umat manusia, memaparkan hidup manusia dalam berbagai aspek kehidupannya dan mengikuti perkembangannya dari masa yang paling tua hingga dewasa ini Konsep waktu penting bagi sejarah karena tanpa di ketahui dimensi waktu lampau, kini dan masa depan maka sejarah akan mengalami kekacauan karena tidak berpangkal dan berujung.

\section{Konsep Perubahan}

Perubahan merupakan gejala yang umum terjadi pada masyarakat manusia. Dalam konteks kehidupan manusia sebagai makhluk sosial dikenal dua macam perubahan yaitu perubahan sosial (social change) dan perubahan kebudayaan (cultural change). Perbedaan pengertian antara perubahan sosial dan perubahan budaya terletak pada pengertian masyarakat dan budaya yang diberikan, tetapi pada 
umumnya perubahan budaya menekankan pada sistem nilai, sedangkan perubahan sosial pada sistem pelembagaan yang mengatur tingkah laku anggota masyarakat. Beberapa pendapat tentang definisi perubahan sosial budaya berikut ini.

Menurut Kingsley Davis, perubahan sosial merupakan bagian dari perubahan kebudayaan. Perubahan kebudayaan mencakup semua unsur kebudayaan, misalnya kesenian, ilmu pengetahuan, teknologi, dan lain-lain termasuk perubahan-perubahan dalam bentuk serta aturan-aturan organisasi social. Sedangkan Menurut Taylor, mengemukakan bahwa kebudayaan adalah suatu kompleks yang mencakup pengetahuan, kepercayaan, kesenian, norma, hukum, adat istiadat serta kebiasaan dari manusia sebagai warga masyarakat. Perubahan kebudayaan adalah setiap perubahan dari semua unsur kebudayaan tersebut

Berdasarkan uraian di atas dapat disimpulkan bahwa perubahan sosial budaya terjadi secara terusmenerus dari dahulu, sekarang, dan di masa yang akan datang. Perubahan sosial budaya tidak dapat dipisahkan, karena kebudayaan berasal dari masyarakat dan masyarakat tidak mungkin tanpa adanya kebudayaan.

Faktor-faktor yang menyebabkan terjadinya perubahan sosial dan perubahan kebudayaan;

a. Faktor Internal

1) Bertambah dan berkurang penduduk

Pertambahan penduduk yang sangat cepat menyebabkan terjadinya perubahan dalam struktur masyarakat, terutama yang menyangkut lembaga-lembaga kemasyarakatan. Lembaga sistem hak milik atas tanah mengalami perubahan-perubahan, orang mengenal hak milik individual atas tanah, sewa tanah, gadai tanah, bagi hasil dan sebagainya, yang sebelumnya tidak dikenal oleh masyarakat.

2) Penemuan-penemuan baru

Inovasi atau innovation merupakan suatu proses sosial dan budaya yang besar, tetapi dalam jangka waktu yang tidak terlalu lama. Proses tersebut meliputi suatu penemuan unsur baru budaya, unsur kebudayaan baru tersebut disebarkan ke masyarakat, lalu diterima, dipelajari dan akhirnya dipakai dalam masyarakat yang bersangkutan. Penemuan-penemuan baru dapat dibedakan menjadi dua yaitu discovery dan invention. Discovery adalah penemuan dari suatu unsur kebudayaan yang baru, baik yang berupa alat baru atau ide baru, yang diciptakan oleh individu atau suatu rangkaian ciptaan individu-individu dalam masyarakat yang bersangkutan. Discovery baru menjadi invention jika masyarakat sudah mengakui, menerima, dan menerapkan penemuan baru tersebut dalam hidup dan kehidupannya.

3) Pertentangan (konflik) dalam masyarakat

Pertentangan (konflik) dalam nilai-nilai dan norma-norma, politik, etnis, dan agama dapat menimbulkan perubahan sosial budaya yang luas.Pertentangan individu terhadap nilai-nilai dan norma-norma, serta adat-istiadat yang telah berjalan lama akan menimbulkan perubahan apabila individu-individu tersebut beralih dari nilai, norma, dan adat-istiadat yang telah diikuti selama ini.

4) Terjadinya pemberontakan atau revolusi di dalam masyarakat

Revolusi yang terjadi di Rusia, Oktober 1917 telah menyebabkan terjadinya perubahanperubahan besar di negara tersebut. Rusia yang mula-mula mempunyai bentuk kerajaan yang absolut yang disebut Tsar, berubah menjadi diktator proletariatyang didasarkan pada doktrin marxisme. Seluruh lembaga-lembaga kemasyarakatan mulai bentuk negara sampai keluarga batih mengalami perubahan yang mendasar. Begitu pula Revolusi Amerika, Revolusi Perancis, dan Revolusi Meiji di Jepang. 
b. Faktor-faktor dari luar (Faktor Eksternal)

1) Peperangan

Peperangan yang terjadi antara satu masyarakat atau negara dengan masyarakat lain menimbulkan berbagai dampak, sepertinya dampak yang ditimbulkan oleh adanya pemberontakan dan pertentangan-pertentangan. Negara yang menang biasanya akan memaksakan negara yang takluk untuk menerima kebudayaannya yang dianggap kebudayaannya lebih tinggi tarafnya.

2) Pengaruh kebudayaan masyarakat lain

Adanya interaksi langsung antara satu masyarakat dengan masyarakat lain akan menyebabkan saling pengaruh. Selain itu, pengaruh budayadapat berlangsung pula melalui komunikasi satu arah yaitu komunikasi masyarakat dengan media massa. Interaksi budaya tidak menjamin timbulnya pengaruh satu budaya terhadap budaya lainnya. Suatu masyarakat dapat saja menolak atau menyeleksinya terlebih dahulu baru kemudian menyerap unsur-unsur budaya yang sesuai.

\section{Konsep Kebudayaan}

Kata kebudayaan berasal dari kata Sansekerta "buddhayah", yaitu bentuk jamak dari "buddh" $i$ yang berarti budi atau akal. Dengan demikian secara sederhana kebudayaan dapat diartikan hal-hal yang bersangkutan dengan akal (Koentjaraningrat, 1979:195).

Selain itu, ada yang mengupas kata budaya sebagai perkembangan dari kata majemuk budi-daya, yang mempunyai arti daya dari budi. Oleh karena itu mereka membedakan "budaya" dari "kebudayaan". Budaya adalah daya dari budi yang berup a cipta, rasa, dan karsa, sedangkan kebudayaan adalah hasil dari cipta, rasa dan karsa. Dengan kata lain, hasil dari ketiga unsur akal atau budi (cipta, rasa, dan karsa) itulah yang disebut dengan kebudayaan. Untuk lebih memahami konsep kebudayaan, berikut ini dikutip beberapa definisi kebudayaan sebagaimana dikutip oleh Widyosiswoyo (1996:33. 34) antara lain:

Menurut Koentjaraningrat, kebudayaan itu keseluruhan sistem gagasan, tindakan, dan hasil karya manusia dalam rangka kehidupan masyarakat yang dijadikan milik diri manusia dengan cara belajar. Menurut Ki Hadjar Dewantara, Kebudayaan berarti buah budi manusia yaitu hasil perjuangan manusia terhadap dua pengaruh kuat, yakni alam dan zaman (kodrat dan masyarakat) yang merupakan bukti kejayaan hidup manusia untuk mengatasi berbagai tantangan dalam hidup dan penghidupannya, guna mencapai keselamatan dan kebahagiaan yang pada lahirnya bersifat tertib dan damai.

Sedangkan menurut Menurut Sutan Takdir Alisyahbana, mengatakan bahwa kebudayaan adalah manifestasi dari cara berpikir sehingga menurutnya pola kebudayaan itu sangat luas, sebab semua perilaku dan perbuatan tercakup di dalamnya dan dapat diungkapkan pada basis dan cara berpikir termasuk di dalamnya perasaan, karena perasaan juga merupakan maksud dari pikiran. Lebih lanjut Menurut C. A. van Peursen, mengatakan bahwa dewasa ini kebudayaan diartikan sebagai manifestasi kehidupan setiap orang dan kehidupan setiap kelompok orang berlainan dengan hewan, maka manusia tidak dapat hidup begitu saja di tengah alam. Oleh karena itu, untuk dapa hidup manusia harus mengubah segala sesuatu yang telah disediakan oleh alam. Misalnya, adanya beras agar dapat dikonsumsi harus diubah dulu menjadi nasi.

Unsur kebudayaan dalam Kamus Besar Bahasa Indonesia berarti bagian suatu kebudayaan yang dapat digunakan sebagai satuan analisis tertentu. Dengan adanya unsur tersebut, kebu dayaan lebih mengandung makna totalitas dari pada sekedar penjumlahan unsur-unsur yang terdapat di dalamnya. Menurut Clyde Kluckhohn ada tujuh unsur kebudayaan yang universal. Ketujuh unsur kebudayaan tersebut adalah sebagai berikut:

a. Bahasa 
Ernst Cassirer (1987:41) menyatakan bahwa manusia adalah makhluk yang menggunakan simbol (animal symbolicum), artinya manusia adalah makhluk yang menggunakan symbol khususnya bahasa. Dengan kata lain, bahasa berisi simbol atau lambang untuk mengkomunikasikan ide, gagasan atau pemikiran.

b. Sistem peralatan dan perlengkapan hidup manusia atau sistem teknologi

Menurut Notonagoro (1987) manusia adalah makhluk yang bersifat monopluralis (jamak tetapi satu) yang terdiri dari susunan kodrat, sifat kodrat, dan kedudukan kodrat. Susunan kodrat manusia terdiri atas jiwa dan raga, sedangkan jiwa mempunyai apa yang disebut dengan cipta, rasa, dan karsa. Dengan cipta, rasa dan karsa inilah manusia mampu menciptakan apa yang disebut teknologi. Teknologi adalah semua cara dan alat yang dipergunakan manusia untuk memenuhi kebutuhannya yang meliputi alat-alat produksi, distribusi dan transportasi, wadah dan tempat untuk menyimpan makanan dan minuman, pakaian dan perhiasan, tempat berlindung dan perumahan serta senjata. Dengan alat-alat ciptaannya itu, manusia dapat lebih mampu mencukupi kebutuhannya dari pada binatang.

c. Sistem mata pencaharian hidup atau sistem ekonomi

Jika dilihat dari tingkat teknologi yang dipergunakan, maka sistem mata pencaharian hidup dapat dibagi atas (Winataputra, 2003): Masyarakat pemburu dan peramu (hunter and gathering), Pertanian berpindah-pindah atau berladang (primitive farming), Peratanian intensif (intensive farming), dan Industri (manufacturing)

d. Sistem kemasyarakatan atau organisasi sosial atau sistem sosial

Keluarga merupakan unit terkecil dari masyarakat sebagai suatu kesatuan. Dalam setiap masyarakat pada umumnya mempunyai aturan tentang tempat tinggal pasangan suami isteri yang baru kawin.

e. Sistem pengetahuan

Pengetahuan adalah segala sesuatu yang diketahui oleh manusia dengan cara belajar, baik belajar dari lingkungan alam, lingkungan sosial maupun lingkungan budayanya. Pengetahuan yang sifatnya universal meliputi pengetahuan tentang tumbuh-tumbuhan (flora) dan binatang (fauna), ruang dan waktu, bilangan, tubuh manusia, dan perilaku antar sesame manusia. Pengetahuan tentang alam tumbuh-tumbuhan merupakan salah satu pengetahuan dasar bagi masyarakat yang mempunyai mata pencaharian pertanian.

\section{f. Sistem Religi (kepercayaan)}

Adanya keterbatasan manusia dalam memahami, memikirkan dan menganalisa keadaan dan kejadian alam dan peristiwa-peristiwa dalam kehidupan sehari-hari, seperti gempa bumi, gunung meletus, kelahiran, kematian, ada orang jahat, ada orang sombong, dan perilaku lainnya yang menyimpang dari nilai dan norma masyarakat, menyebabkan manusia sadar akan adanya kekuatan di luar dirinya sendiri yang disebut kekuatan supranatural.

Dengan adanya kesadaran terhadap kekuatan supranaturalmelahirkan sistem kepercayaan. Seperti kepercayaan kepada roh nenek moyang (animisme), kepercayaan kepada kekuatan alam (dinamisme), kepercayaan yang menganggap suci terhadap binatang tertentu (totemisme), pemujaan kepada pelaksana upacara (shamanisme), percayakepada dewa-dewa, dan sebagainya. Agama berbeda dengan aliran kepercayaan. Agama adalah keyakinan yang harus diterima oleh penganutnya dan memuat berbagai aturan tentang sesuatu yang harus dipatuhi. Sifat agama adalah menuntun penganutnya agar mendapat keselamatan baik di dunia maupun di akhirat.

Agama berasal dari bahasa Sansekerta artinya tidak, gamaartinya kacau. Jadi agama tidak kacau atau teratur. Agama yang diakui oleh pemerintah Indonesia adalah Islam, Katolik,Kristen, Hindu, dan 
Buda. Agama menjadi identitas setiap penganutnya, memberikan dorongan spiritual dalam bertingkah laku, memberi arah dalam menjalani kehidupan di dunia. Dengan adanya ketaatan dalam menjalankan agama, maka tercipta kedisiplian, ketekunan, rasa kebersamaan, saling hormat-menghormati, jujur, dan sebagainya. Semuanya itu sangat diperlukan dalam menjalin hubungan, baik individu dengan Tuhannya, individu dengan individu, maupun individu dengan masyarakat.

g. Sistem Kesenian

Berbagai macam kesenian tersebut merupakan pranata yang dipergunakan untuk mengekspresikan rasa keindahan dari dalam jiwa manusia yang bersumber pada perasaan. Seperti menggambar pada sebagian anggota tubuh (tatto) tujuannya awalnya adalah untuk menyamar dari musuh dan binatang buruan. Mengenai seni patung dan seni pahat (relief pada candi), seni tari di Bali tidak dapat dipisahkan perkembangannya dari agama Hindu dan Budha. Semakin berkembang teknologi, semakin bervariasi pula usaha manusia untuk mengekspresikan rasa keindahannya dalam bentuk berbagai jenis kesenian.

\section{KESIMPULAN}

Konsep waktu dalam pembelajaran ilmu sosial erat kaitannya dengan ilmu sejarah yang meliputi masa lalu, masa sekarang dan yang akan datang, begitu juga dalam pembelajaran ilmu sosial lainnya, yang diintegrasikan secara terpadu dalam pembelajaran IPS, yang pada hakekatnya. Perubahan merupakan gejala yang umum terjadi pada masyarakat manusia. Dalam konteks kehidupan manusia sebagai makhluk sosial dikenal dua macam perubahan yaitu perubahan sosial (social change) dan perubahan kebudayaan (cultural change). Sedangkan kebudayaan adalah hasil dari daya dari budi yang berupa cipta, rasa, dan karsa, manusia sebagai nilai yang dijunjung tinggi dan membentuk aturan yang disepakati besara untuk kepentingan bersama anggota kelompok masyarakat. Dengan kata lain, hasil dari ketiga unsur akal atau budi (cipta, rasa, dan karsa) itulah yang disebut dengan kebudayaan.

\section{Daftar Pustaka}

Abdullah, Taufik, dkk. (1985). Sejarah dan Historiografi. Jakarta: Gramedia.

Affandi, Idrus. (1997). Tata Negara. Jakarta: Departemen Pendidikan dan Kebudayaan.

Ali, Moh, R. (1961). Pengantar Ilmu Sejarah Indonesia. Jakarta: Bharata.

Daldjoeni, N. (1984). Geografi Kesejarahan. Bandung: Alumni.

Gazalba, Sidi. (1981). Pengantar Ilmu Sejarah. Jakarta: Bharata.

Gottschalk, Louis (1975). Mengerti Sejarah. Terjemahan. Nugroho Notosusanto. Jakarta: Universitas Indonesia.

Ismauan. (1988). Diklat Pengantar Ilmu Sejarah. Bandung: EKT.

Kartodirdjo, S. (1983). Pendekatan Ilmu Sosial dalam Metodologi sejarah. Jakarta: Gramedia Pustaka Utama.

Koentjaraningrat. (1962). Antropolgi. Jakarta: Bharata.

Mulyadi, Yad. (1999). Antropolgi. Jakarta: Departemen Pendidikan dan Kebudayaan.

Sunatra dan Dasim Budimansyah. (1987). Sosiologi dan Antropologi. Bandung: Epsilon Grup.

Trijono, Lambang dan Suharko. (1998). Sosiologi. Jakarta: Departemen Pendidikan dan Kebudayaan. 